\title{
Electrodeposition of ZnTe Compound Semiconductors from Aqueous Solution
}

\author{
Takeshi Ohgai, Takashi Ikeda, Yasuyuki Kawanaka, \\ Keizo Takao and Akio Kagawa
Department of Materials Science and Engineering, Faculty of Engineering, Nagasaki University, 1-14 Bunkyo-machi, Nagasaki, 852-8521, Japan
Email: ohgai@nagasaki-u.ac.jp

Keywords: Electrodeposition, Semiconductor, ZnTe, UPD

\begin{abstract}
ZnTe compound semiconductors were synthesized in acidic aqueous solution using a pulsed current electrodeposition technique. The optimum condition to obtain ZnTe deposits was determined by the cathodic polarization curves measured at a wide potential range. During the co-deposition of $\mathrm{Zn}$ and Te, under potential deposition (UPD) of $\mathrm{Zn}$ was observed. Increasing the solution temperature up to $353 \mathrm{~K}$, UPD of $\mathrm{Zn}$ was promoted by the formation of $\mathrm{Zn}(\mathrm{OH})_{2}$. Crystal phase, structure and chemical composition of electrodeposited ZnTe was controlled by the solution composition and electrolysis condition. The band gap energy of ZnTe films annealed at $573 \mathrm{~K}$ was close to $2.26 \mathrm{eV}$.
\end{abstract}

\section{Introduction}

Zinc based II-VI compound semiconductors ( $\mathrm{ZnO}, \mathrm{ZnS}, \mathrm{ZnSe}, \mathrm{ZnTe}$, etc.) with wide band gap energy can be applied to the opto-electronic devices such as light emission devices and photovoltaic solar cells [1-2]. Among of the zinc based II-VI compound semiconductors, ZnTe can be applied to green light emission devices and photovoltaic solar cells because the band gap energy of ZnTe is 2.26 $\mathrm{eV}$. The $\mathrm{ZnTe}$ thin films grown at room temperature and high temperature are found to be polycrystalline in nature. Polycrystalline thin films of ZnTe have been prepared using different techniques such as, thermal evaporation [3], sputtering [4], chemical vapor deposition [5] and electrodeposition [6-10]. The equipment for liquid-based techniques is simple and much less costly than vacuum systems. Te can be electrodeposited from acidic aqueous solution and is not as harmful as the elements $\mathrm{As}, \mathrm{Cd}, \mathrm{Pb}$ and $\mathrm{Se}$. Electrodeposition technique offers a low cost growth method to deposit good quality ZnTe thin films. This technique also allows the coating over large areas with good lateral control of the material quality. In this paper, to determine the optimum condition, electrodeposition process of $\mathrm{Zn}$-Te compound semiconductors from acidic aqueous solution was investigated.

\section{Experimental}

Electrolytic solution was synthesized from $\mathrm{ZnSO}_{4}$ and $\mathrm{TeO}_{2}$ as shown in Table 1. The solution $\mathrm{pH}$ was adjusted by adding $\mathrm{H}_{2} \mathrm{SO}_{4}$ and $\mathrm{NaOH}$. The solution temperature was maintained to $353 \mathrm{~K}$ during the electrodeposition. Indium tin oxide (ITO) glass and gold wire were used as a cathode and an anode, while the $\mathrm{Ag} / \mathrm{AgCl}$ electrode immersed in saturated $\mathrm{KCl}$ solution was used as the reference electrode. ZnTe film was potentiostatically electrodeposited on the ITO glass. Crystal structure of the deposited films was analyzed by using X-ray diffraction (XRD). The chemical composition was determined by means of energy dispersive X-ray spectrometer (EDX). Band gap energy of the deposited films was estimated by using ultraviolet and visible spectrophotometer (UV). 
Table 1 Electrolytic solution composition for electrodeposition of $\mathrm{ZnTe}$ from aqueous solution.

\begin{tabular}{ccccccc}
\hline \hline sample & $\begin{array}{c}\mathrm{ZnSO}_{4} \cdot 7 \mathrm{H}_{2} \mathrm{O} \\
(\mathrm{mM})\end{array}$ & $\begin{array}{c}\mathrm{TeO}_{2} \\
(\mathrm{mM})\end{array}$ & $\begin{array}{c}\mathrm{Na}_{2} \mathrm{SO}_{4} \\
(\mathrm{mM})\end{array}$ & $\begin{array}{c}\mathrm{H}_{3} \mathrm{Cit} \\
(\mathrm{mM})\end{array}$ & $\begin{array}{c}\mathrm{Na}_{3} \mathrm{Cit} \cdot 2 \mathrm{H}_{2} \mathrm{O} \\
(\mathrm{mM})\end{array}$ & \\
\hline $\mathrm{No} .1$ & 100 & 0.1 & 500 & 10 & 10 & \\
$\mathrm{No.2}$ & 100 & 0.1 & 500 & 10 & 10 & $\mathrm{H}_{3} \mathrm{BO}_{3}: 500 \mathrm{mM}$ \\
$\mathrm{No}$ & 100 & 0.1 & 500 & 10 & 10 & $\mathrm{~N}_{2}$ gas Bubbling \\
No.4 & 100 & 0.1 & 500 & - & - & Maric acid : $30 \mathrm{mM}$ \\
& & & & & & \multicolumn{2}{c}{ Concentration $\left(\mathrm{M}=\mathrm{mol} \mathrm{dm}^{-3}\right)$}
\end{tabular}

\section{Results and Discussions}

\section{Electrodeposition Process}

Figure 1 shows cathodic polarization curves for $\mathrm{Zn}$-Te electrodeposition. The polarization curves obtained from the solution containing $\mathrm{H}_{3} \mathrm{BO}_{3}$ (No.2) and the solution bubbled by blowing $\mathrm{N}_{2}$ gas (No.3) are also shown in the figure. $\mathrm{H}_{3} \mathrm{BO}_{3}$ in the solution acts as $\mathrm{pH}$ buffer substance and $\mathrm{N}_{2}$ gas in the solution prevents $\mathrm{TeCit}^{+}$ions from oxidation. At the potential of ca. $-0.2 \mathrm{~V}, \mathrm{H}^{+}$ions began to be reduced. With increasing the current up to $10^{-6} \mathrm{~A}$, the potential polarized to around $-0.5 \mathrm{~V}$ and $\mathrm{Te}$ began to deposit. With increase in the current over $10^{-5} \mathrm{~A}$, the potential polarized from $-0.5 \mathrm{~V}$ to -1.0 $\mathrm{V}$. In this potential range, the $\mathrm{pH}$ in the vicinity of the cathode can increase up to around 6 due to the diffusion limit of $\mathrm{H}^{+}$ions and $\mathrm{TeCit}^{+}$ions, then $\mathrm{Zn}(\mathrm{OH})_{2}$ forms in the vicinity of cathode. Electrodeposition of $\mathrm{ZnTe}$ will proceed by $\mathrm{Zn}$ UPD due to the formation of $\mathrm{Zn}(\mathrm{OH})_{2}$ by the following reaction.

$$
\mathrm{Zn}(\mathrm{OH})_{2}+\mathrm{TeCit}^{+}+2 \mathrm{H}^{+}+6 \mathrm{e}^{-} \rightarrow \mathrm{ZnTe}+2 \mathrm{H}_{2} \mathrm{O}+\mathrm{Cit}^{3-}
$$

Zn-Te films deposited in the potential range from $-0.8 \mathrm{~V}$ to $-0.9 \mathrm{~V}$ mainly contained ZnTe phase with stoichiometric composition. Furthermore, with increase in the current more than $10^{-4} \mathrm{~A}$, the potential polarized to less-noble than $-1.0 \mathrm{~V}$. In the potential range, massive metallic $\mathrm{Zn}$ began to deposit from $\mathrm{Zn}^{2+}$ ions.

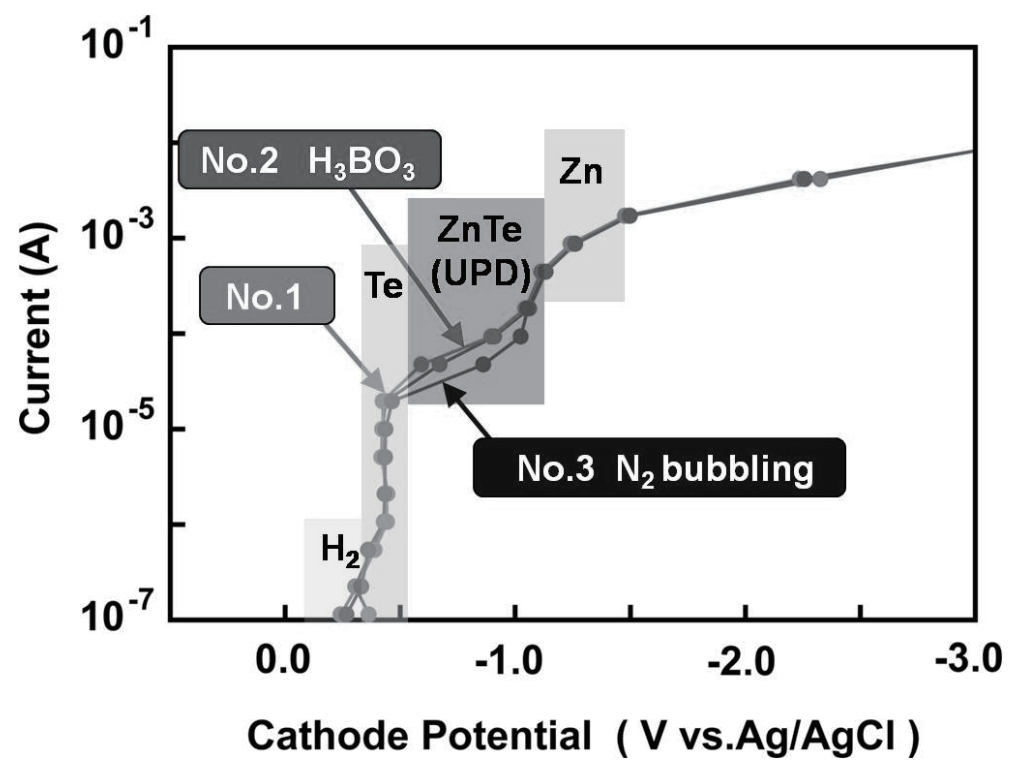

Figure 1 Cathodic polarization curves for Zn-Te electrodeposition. (No.1: standard solution, No.2: solution containing $\mathrm{H}_{3} \mathrm{BO}_{3}$, No.3: solution bubbled by blowing $\mathrm{N}_{2}$ gas.) 


\section{Crystal Structure and Band Gap Energy}

XRD patterns of electrodeposited films are shown in Fig.2. These XRD patterns correspond to (111) reflection planes of zincblende type ZnTe. During the electrodeposition of $\mathrm{ZnTe}$, hydrogen ions are also reduced and $\mathrm{pH}$ in the vicinity of cathode increases up to around 6 . At this $\mathrm{pH}, \mathrm{Zn}(\mathrm{OH})_{2}$ forms in the vicinity of cathode. UPD of zinc during $\mathrm{ZnTe}$ electrodeposition is caused by the formation of $\mathrm{Zn}(\mathrm{OH})_{2} \cdot \mathrm{H}_{3} \mathrm{BO}_{4}$ in the solution acts as $\mathrm{pH}$ buffer substance and prevent $\mathrm{Zn}(\mathrm{OH})_{2}$ from forming in the vicinity of cathode. Therefore, the sample obtained from the solution containing $\mathrm{H}_{3} \mathrm{BO}_{3}$, consists of ZnTe and Te phase as shown in Fig.2-(b). ZnTe films with almost stoichiometric composition $(\mathrm{Zn}: \mathrm{Te}=1: 1)$ were obtained at under potential range more noble than $-1.0 \mathrm{~V}$ vs. $\mathrm{Ag} / \mathrm{AgCl}$.

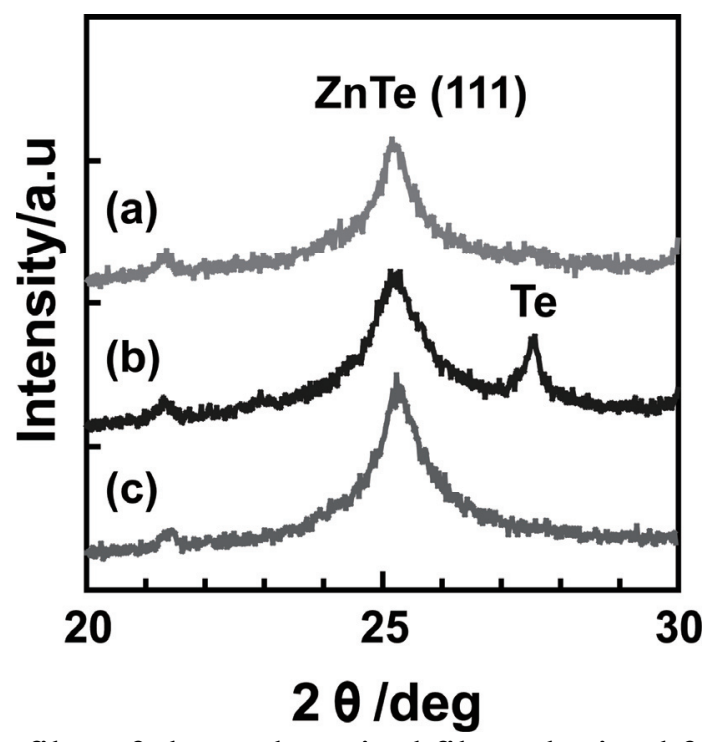

Figure $2 \mathrm{X}$-ray diffraction profiles of electrodeposited films obtained from three different conditions. Standard condition (a), solution containing $\mathrm{H}_{3} \mathrm{BO}_{3}$ (b) and bubbling with $\mathrm{N}_{2}$ gas (c).

Table 2 and 3 show the band gap energy of electrodeposited Zn-Te films without heat treatment (Table 2) and with annealing at $573 \mathrm{~K}$ (Table 3). As shown in Table 2, band gap energy of as-deposited ZnTe films was less than $1.5 \mathrm{eV}$, which is smaller than the ideal band gap $2.26 \mathrm{eV}$ of $\mathrm{ZnTe}$. On the other hand, the band gap energy of ZnTe films after annealing at $573 \mathrm{~K}$ was close to $2.26 \mathrm{eV}$. This results from the disappearance of crystal defects and the recrystallization of the electro-deposited ZnTe fine crystals.

Table 2 Band gap energy of electrodeposited Zn-Te films without heat treatment.

\begin{tabular}{|c|c|c|c|c|c|}
\hline Potential (V) & -0.6 & -0.7 & -0.8 & -0.9 & -1.0 \\
\hline No.1 (eV) & - & 1.29 & 1.37 & 1.50 & 1.53 \\
\hline No.2 (eV) & 1.10 & 1.22 & 1.44 & 1.44 & 1.38 \\
\hline No.3 (eV) & 1.04 & 1.24 & 1.20 & 1.13 & - \\
\hline No.4 (eV) & 1.28 & 1.15 & 1.03 & 0.88 & - \\
\hline
\end{tabular}

Table 3 Band gap energy of electrodeposited $\mathrm{Zn}$-Te films with annealing at $573 \mathrm{~K}$.

\begin{tabular}{|c|c|c|c|c|c|}
\hline Potential (V) & -0.6 & -0.7 & -0.8 & -0.9 & -1.0 \\
\hline No. 1 (eV) & - & 1.68 & 1.84 & 1.84 & 2.18 \\
\hline No. 2 (eV) & 1.67 & 1.22 & 1.30 & 1.48 & 1.50 \\
\hline No.3 (eV) & 1.14 & 2.08 & 1.90 & 1.96 & - \\
\hline No. 4 (eV) & 1.43 & $\overline{2.10}$ & 2.02 & $\overline{1.08}$ & - \\
\hline
\end{tabular}




\section{Conclusions}

Co-deposition of zinc and tellurium proceeded at potential region more noble than the equilibrium potential of zinc. Optimum deposition potential to obtain ZnTe single phase was determined to the range from $-0.8 \mathrm{~V}$ to $-0.9 \mathrm{~V}$. By raising the solution temperature up to $353 \mathrm{~K}$, the formation of $\mathrm{Zn}(\mathrm{OH})_{2}$ and the electrodeposition of $\mathrm{ZnTe}$ were promoted. $\mathrm{Zn}$ UPD due to the formation of $\mathrm{Zn}(\mathrm{OH})_{2}$ promoted the electrodeposition of $\mathrm{ZnTe}$ with stoichiometric composition. Cubic zincblende type ZnTe compound semiconductor was potentiostatically electrodeposited on ITO glass from aqueous solution. The band gap energy of ZnTe films annealed at $573 \mathrm{~K}$ was close to the ideal value of 2.26 $\mathrm{eV}$.

\section{Acknowledgements}

This work was supported in part by JFE 21st Century Foundation and Japan Society for the Promotion of Science (Grant-in-aid for Scientific Research C : No. 21560748).

\section{References}

[1] J. Gu, K. Tonomura, N. Yoshikawa, T. Sakaguchi, J. Appl. Phys. 44, 4692 (1973).

[2] C. Winnewisser, P.U. Jepsen, M. Schall, V. Schiyja, H. Helm, Appl. Phys. Lett. 70, 3069 (1997).

[3] U. Pal, S. Saha, A.K. Chaudhuri, V.V. Rao, H.D. Banerjee, J. Phys. D: Appl. Phys. 22, 965 (1989).

[4] H. Bellakhder, A. Outzourhit, E.L. Ameziane, Thin Solid Films, 382, 30 (2001).

[5] K. Wolf, H. Stanzl, A. Naumov, H.P. Wagner, W. Kuhn, B. Kahn, W. Gebhardt, J. Cryst. Growth, 138, 412 (1994).

[6] M. Neumann-Spallart, C. Königstein, Thin Solid Films, 265, 33 (1995).

[7] C. Königstein, M. Neumann-Spallart, J. Electrochem. Soc. 145, 337 (1998).

[8] B. Bozzini, M.A. Baker, P.L. Cavallotti, E. Cerri, C. Lenardi, Thin Solid Films, 361-362, 388 (2000).

[9] M.-C. Lin, P.-Y. Chen, I.-W. Sun, J. Electrochem. Soc. 148, 653 (2001).

[10] D.H. Han, S.J. Choi, S.M. Park, J. Electrochem. Soc. 150, 342 (2003). 